\title{
Comparison of Three Aluminum Coagulants for Phosphorus Removal
}

\author{
Junling Wang ${ }^{*}$, Jian Song1, Jun Lu², Xin Zhao ${ }^{3}$ \\ ${ }^{1}$ Key Laboratory of Urban Stormwater System and Water Environment (Beijing University of Civil Engineering \\ and Architecture), Ministry of Education, Beijing, China \\ ${ }^{2}$ Beijing Xingchuang Investment Company Limited, Beijing, China \\ ${ }^{3}$ Beijing Municipal Road \& Bridge Corporation Limited, Beijing, China \\ Email: *wangjunling@bucea.edu.cn
}

Received 10 May 2014; revised 8 June 2014; accepted 1 July 2014

Copyright (C) 2014 by authors and Scientific Research Publishing Inc.

This work is licensed under the Creative Commons Attribution International License (CC BY).

http://creativecommons.org/licenses/by/4.0/

c) (7) Open Access

\begin{abstract}
That phosphorus has been removed more from water in purification process can result in higher grade of biological stability of the effluent tap water, especially for the water plant when using surface water source. This study conducted the experiments of phosphorus removal by three coagulants including aluminum chloride, aluminum sulfate and poly aluminum chloride. The results indicated that the poly aluminum chloride is the preferred one that could remove phosphorus up to $80 \%$, followed by aluminum chloride and aluminum sulfate. The lowest proportion of aluminum quality to phosphorus quality is 63 as using poly aluminum chloride, followed by aluminum chloride and aluminum sulfate. It is suggested that the poly aluminum chloride should be the best option to remove phosphorus in water plant.
\end{abstract}

\section{Keywords}

Aluminum Chloride, Aluminum Sulfate, Poly Aluminum Chloride, Phosphorus Removal

\section{Introduction}

A comprehensive study of the biological stability has been undertaken [1]-[3]. It has been demonstrated that the phosphorus is a limiting factor for microorganism growth in tap water [4] [5]. If the SRP (soluble reactive phosphorus) concentration is below $10 \mu \mathrm{g} / \mathrm{L}$, the growth of bacteria would be limited. Because nowadays the water source has been polluted seriously for many water plants, of which the microbe would grow in tap water and the biological instability would occur. In case of the above mentioned, the removal efficiency should be re-

\footnotetext{
${ }^{*}$ Corresponding author.
} 
searched in order to find new ways and increase the stability of tap water.

In the coagulation process of water plant, the aluminum salts are usually used as coagulant including poly aluminum chloride, alumina sulfate and aluminum chloride. The removal rate for phosphorus by aluminum salt and comparison of three general aluminum salts should be researched. This study is helpful to probe the removal rate of phosphorus in traditional water purification process, and promote to develop new coagulant for larger removal rate of phosphorus.

\section{Experimental Material and Apparatus}

Apparatus: six combined agitator.

Raw water: Zhuan River water.

Experimental material: aluminum chloride, aluminum sulfate, poly aluminum chloride.

\section{Experiment and Analysis}

\subsection{Aluminum Chloride}

The aluminum is usually used in many water plants as one main coagulant and it could remove phosphorus partly. In this study the influent water was fetched from the Zhuan River in Beijing, and the TP (total phosphorus) concentration is $185.36 \mu \mathrm{g} / \mathrm{L}$. The rapid rotating rate, moderate rotating rate, low rotating rate of agitator are set at $700 \mathrm{r} / \mathrm{min}$ for $40 \mathrm{~s}, 400 \mathrm{r} / \mathrm{min}$ for $5 \mathrm{~min}$, and $80 \mathrm{r} / \mathrm{min}$ for $10 \mathrm{~min}$ respectively. The influent water $\mathrm{pH}$ value was set at 7 , the temperature is $16^{\circ} \mathrm{C}$, and the sedimentation time was set for $20 \mathrm{~min}$. the removal efficiency of TP, PP (particulate phosphorus) and SP (soluble phosphorus) was determined with different dosage of aluminum chloride. The experimental result was shown in Figure 1 . If the dosage is $50 \mathrm{mg} / \mathrm{L}$ (as $\mathrm{AlCl}_{3}$ ), the largest removal rate would reach up to $74.9 \%$.

As can be seen from the Figure 2, the removal rate of total phosphorus is increasing gradually with the increase of dosage. But the removal rate would decline when the dosage is over $74.9 \%$. The concentration of SP in effluent water decreases gradually with the increasing of dosage. However, the PP concentration increases with the adding of dosage. It is present that the SP would be removed with increase of dosage [6], and it present that the PP removal rate is adversely to the over dosage. The best dosage is $0.375 \mathrm{mmol} / \mathrm{L}$ (as $\mathrm{Al}^{3+}$ ), the phosphorus removed is $0.00448 \mathrm{mmol} / \mathrm{L}$, and the proportion of aluminum to phosphorus is 84 . As the best $\mathrm{pH}$ value to remove phosphorus by aluminum chloride, Qiuyang Wang [7] has described that the optimum $\mathrm{pH}$ value is 6.5 8.5 to remove phosphorus in wastewater.

\subsection{Aluminum Sulfate}

AS (aluminum sulfate) is a kind of crystal, and the molecular formula of it is $\mathrm{Al}_{2}\left(\mathrm{SO}_{4}\right)_{3} \cdot \mathrm{n} \mathrm{H}_{2} \mathrm{O}$. In light of the water loss condition, the $\mathrm{n}$ would be $6,14,16,18,37$, and the general one is the crystal with $18 \mathrm{H}_{2} \mathrm{O}$, the $\mathrm{Al}_{2}\left(\mathrm{SO}_{4}\right)_{3} \cdot 18 \mathrm{H}_{2} \mathrm{O}$. The molecular weight of it is 666.41 , and the relative density is 1.61 . Aluminum sulfate is soluble to water, the water is acid and the solubility is $50 \%$ at room temperature.

Since aluminum sulfate was developed in America in the early 1884, it has been used in great deal of water plants. At the same time, aluminum salt has occupied large part of the market. So far, aluminum salt has been the coagulant that was most widely used and produced with largest amount. The transportation of aluminum sulfate is convenient, the management of operating is simple, and the coagulating efficiency is better. However, the aluminum sulfate hydrolyzes slowly if the temperature is low, and the flocculating constituent will be incompact, lowering the coagulating efficiency.

The TP concentration of the influent water was $51.05 \mu \mathrm{g} / \mathrm{L}$. The rapid, moderate and low rotating speed was set at $700 \mathrm{r} / \mathrm{min}(40 \mathrm{~s}), 400 \mathrm{r} / \mathrm{min}(5 \mathrm{~min})$ and $80 \mathrm{r} / \mathrm{min}(10 \mathrm{~min})$ respectively. The $\mathrm{pH}$ was adjusted at 7 and the temperature is $16^{\circ} \mathrm{C}$, the sedimentation time is $20 \mathrm{~min}$ as well. The removal rate of TP, PP, and SP was tested under the condition of different dosage. The result was depicted in Figure 3 and Figure 4.

As can be seen from Figure 4, with the increasing of dosage, the removal rate of phosphorus increases at the beginning and decreases at the end. If the dosage is $40 \mathrm{mg} / \mathrm{L}$ (as $\left.\mathrm{Al}_{2}\left(\mathrm{SO}_{4}\right)_{3}\right)$, the removal rate could reach the largest. It showed that the SP concentration would decline with the increasing of the dosage, but the PP would increase if the dosage is more than a limit point. When it reaches the largest removal of phosphorus, the dosage of $\mathrm{Al}^{3+}$ is $0.234 \mathrm{mmol} / \mathrm{L}$, the phosphorus removed is $0.00105 \mathrm{mmol} / \mathrm{L}$, and the proportion of aluminum to phosphorus is 223. 


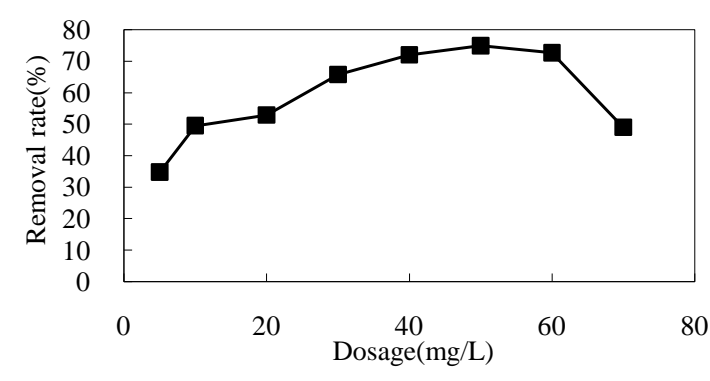

Figure 1. TP removal efficiency with different dosage of $\mathrm{AlCl}_{3}$.

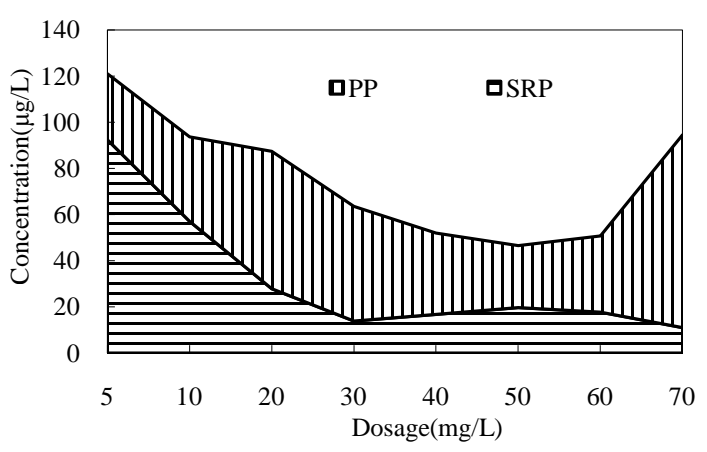

Figure 2. Concentration comparison of various forms of phosphorus by different dosage of $\mathrm{AlCl}_{3}$.

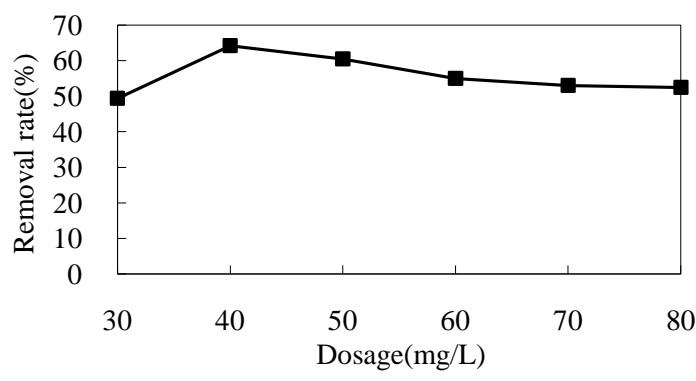

Figure 3. TP removal efficiency with different dosage of AS.

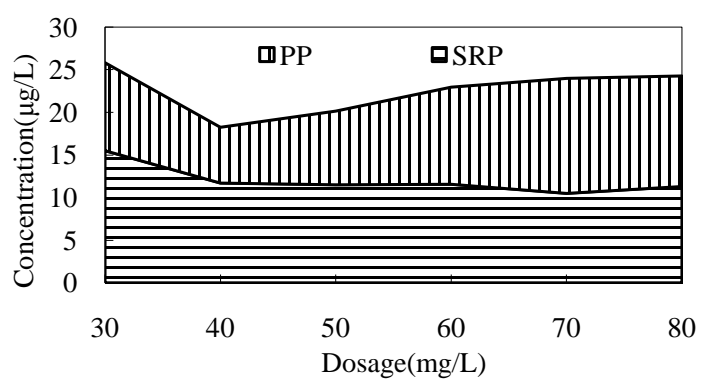

Figure 4. Various forms of phosphorus removal efficiency with different dosage of AS.

As can be seen from the comparison result, the phosphorus removal rate by aluminum sulfate is stable. The largest removal rate of phosphorus by aluminum sulfate is up to $64.2 \%$.

The experiment on the removal efficiency of TP by aluminum sulfate under the different condition of $\mathrm{pH}$ has been conducted. The influent water total phosphorus concentration is $78.74 \mu \mathrm{g} / \mathrm{L}$. the result is depicted in Figure 5 . 


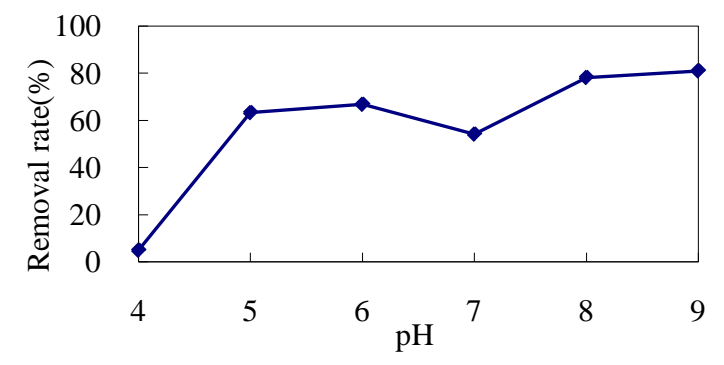

Figure 5. TP removal efficiency with different $\mathrm{pH}$ value of AS.

From the Figure 5, the removal rate of TP was affected by $\mathrm{pH}$. When the $\mathrm{pH}$ varies from 4 to 9 , the removal rate would increase with $\mathrm{pH}$. It illustrated that the phosphorus removal rate would rise in alkaline environment. Because the $\mathrm{pH}$ value is not larger than 9 in this experiment, so it could not clear what the result is when the $\mathrm{pH}$ is larger than 9. Some researchers [8] highlights that the best $\mathrm{pH}$ value is 7.43 for aluminum sulfate, and the effective scale of $\mathrm{pH}$ is in the range from 5.42 to 9.39 , so the result of this paper is accord to that result. Researches [9] address that when the $\mathrm{pH}$ value is from 9.8 to 12 , the $\mathrm{COD}_{\mathrm{Cr}}$ and color could reach the best removal for printing and dyeing wastewater. It has illustrated that the applicable scale of $\mathrm{pH}$ would change for different wastewater and different pollutants.

\subsection{Poly Aluminum Chloride}

The PAC (poly aluminum chloride) was used first time in 1960's in Japan, and then other countries start to produce it in great deal. The molecular formula of $\mathrm{PAC}$ is $\mathrm{Al}_{\mathrm{n}}(\mathrm{OH})_{\mathrm{m}} \mathrm{Cl}_{3 \mathrm{n}-\mathrm{m}}$. It has two types in solid and liquid respectively. The merit of solid matter is the easy transportation and storage, but the inconvenient dissolving. From the point of effectiveness, store condition, and transportation condition, the solid matter is applicable prior to the liquid matter. It has demonstrated that the poly aluminum has three morphologies, one is the $\mathrm{Al}_{\mathrm{a}}$, a kind of monomer, that includes the unstrained irons, monomers and low molecular weight polymers. The second type is $\mathrm{Al}_{\mathrm{b}}$, it is a kind of sheet and cage like. The third one is $\mathrm{Al}_{\mathrm{c}}$, it is a soluble colloid. It is a type of solution of three hydroxyl aluminum or congealed colloid [7].

The influent water came from the Zhuan River that was tested, the phosphorus concentration was $184.51 \mu \mathrm{g} / \mathrm{L}$. The coagulant used is poly aluminum chloride (solid, content of $\mathrm{Al}_{2} \mathrm{O}_{3}$ is $39 \%$ ). The dosage is $0.038-0.266$ $\mathrm{mmol} / \mathrm{L}\left(\mathrm{as} \mathrm{Al}_{2} \mathrm{O}_{3}\right.$ ). The rapid rotating is $700 \mathrm{r} / \mathrm{min}(40 \mathrm{~s})$, and the moderate rotating speed is $400 \mathrm{r} / \mathrm{min}$ (5 min), the low rotating speed is $80 \mathrm{r} / \mathrm{min}(10 \mathrm{~min})$. The $\mathrm{pH}$ value was set at 7 , and the temperature is $22^{\circ} \mathrm{C}$. The sedimentation time is 20 minutes. The experimental result is shown in Figure 6, Figure 7.

It can be seen from the Figure 6, when the dosage is from 0.12 to $0.19 \mathrm{mmol} / \mathrm{L}$, the phosphorus removal rate is better, and the $0.19 \mathrm{mmol} / \mathrm{L}$ is the best dosage to remove phosphorus at the largest removal rate of $79.5 \%$. When the dosage is larger than $0.19 \mathrm{mmol} / \mathrm{L}$, the removal rate would decrease with the dosage increase. From the Figure 7, with the dosage increase, the effluent water SP decreases gradually. It showed that the added coagulant would be inverse effective on the removal of particulate phosphorus. According to this experiment, when the removal rate through poly aluminum chloride reach the largest, the $\mathrm{Al}^{3+}$ added is $0.3 \mathrm{mmol} / \mathrm{L}$, and the removal phosphorus is $0.00474 \mathrm{mmol} / \mathrm{L}$. The proportion of aluminum to phosphorus is $63 / 1$, which is relative to the morphology, proportion, and other existing matter [10]. It is not decided by TP concentration only.

The $\mathrm{pH}$ was set at 4, 5, 6, 7, 8 and 9 respectively, the coagulation parameters are as the above. The influent phosphorus concentration is $43.69 \mu \mathrm{g} / \mathrm{L}$, the experiment result was shown in Figure 8, Figure 9.

As can be seen from the Figure 8, when the $\mathrm{pH}$ is at the range of $4-9$, the removal rate would increase with increasing of the $\mathrm{pH}$. It illustrated that the poly aluminum chloride would remove phosphors better in high alkalinity solution. From the effluent water of each form of phosphorus, the SP is easily to be removed in high alkalinity solution, and the removal rate of particulate phosphorus is not sensitive to change of $\mathrm{pH}$. The optimum $\mathrm{pH}$ is 7 - 9 .

In the light of morphology of phosphate acid, when $\mathrm{pH}$ is less than 4.6, the phosphoric acid contents $\mathrm{H}_{3} \mathrm{PO}_{4}$ mainly. It is uneasy to bond the PAC carrying positive charges and to be removed. When the $\mathrm{pH}$ is at range of 4.6 - 9.8, the $\mathrm{H}_{2} \mathrm{PO}_{4}^{-}$and $\mathrm{HPO}_{4}^{2-}$ are the main forms in phosphoric acid solution [11], and it is intended to 


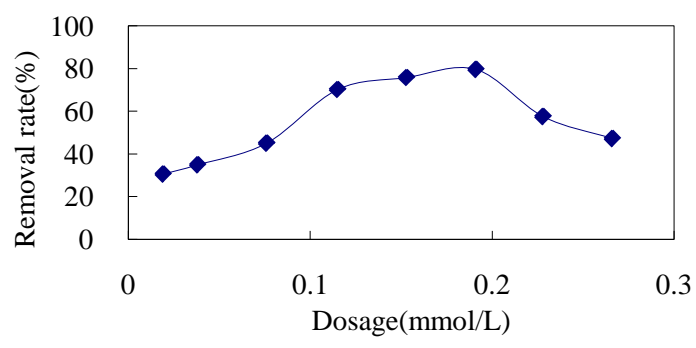

Figure 6. TP removal efficiency with different dosage of PAC.

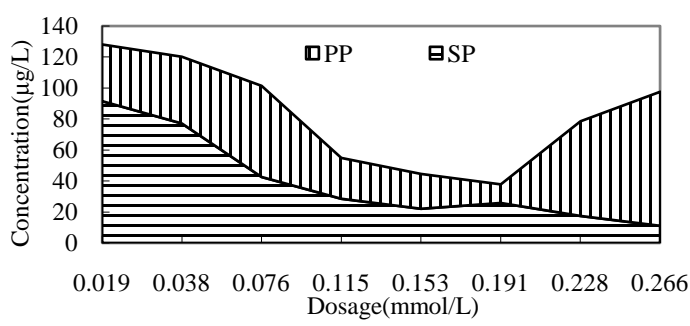

Figure 7. Effluent various forms of phosphrous concentration with different dosage of PAC.

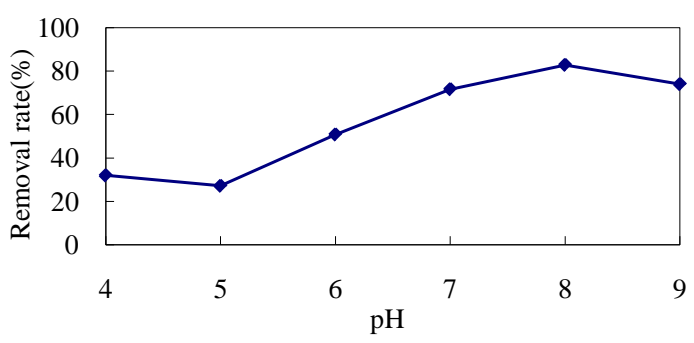

Figure 8. TP removal efficiency with different $\mathrm{pH}$ value of PAC.

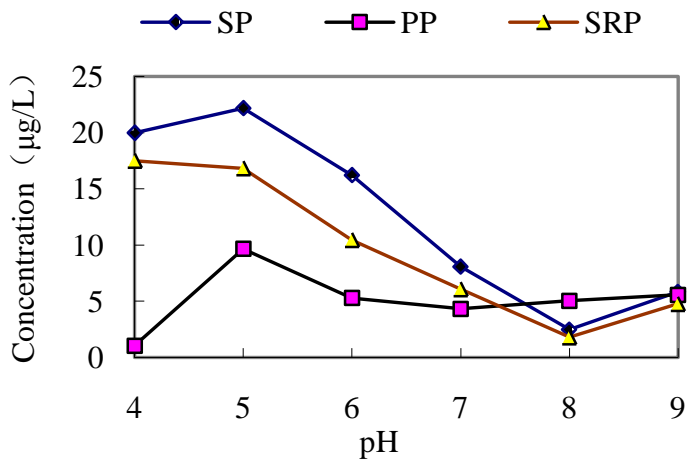

Figure 9. Effluent concentration of various forms of phosphorus with different $\mathrm{pH}$ value.

bond the PAC to be removed. When $\mathrm{pH}$ is at from 9.8 to 14, the $\mathrm{HPO}_{4}^{2-}$ and $\mathrm{PO}_{4}^{3-}$ would be mainly in the solution, and the main morphology of PAC is sub aluminum acid of anions, so the phosphorus removal is bad. So it is proposed that the optimum $\mathrm{pH}$ is from 4.6 to 9.8 .

With the change of $\mathrm{pH}$ in PAC solution, the morphology of aluminum would change. When the $\mathrm{pH}$ is larger than 3 , it is mainly hydrated aluminum irons. When the $\mathrm{pH}$ value grows, the hydrated aluminum iron would hydrolyze, and produce the sole core mono hydroxyl compound. When the $\mathrm{pH}$ increases gradually, the sole core 
mono hydroxyl compound would hydrolyze into three cores mono hydroxyl compounds. When the $\mathrm{pH}$ value is larger than 5 , the deposit of $\mathrm{Al}(\mathrm{OH})_{3}$ would emerge. When the $\mathrm{pH}$ is larger than 8, the matter in solution nearly is the deposit of $\mathrm{Al}(\mathrm{OH})_{3}$.

From the above analysis, the conclusion can be reached that when the inorganic coagulant poly aluminum chloride was solved in the water, it would form polynuclear poly hydroxyl anion, it could react with hydrogen phosphate ions, dihydrogen phosphate ions, form complex large molecular coordination compound, and its water solubility would decrease, the extent of aggregation would be enhanced and settle down. At the same time, the great deals of hydroxide floc sediment would be formed in coagulation process, which has strong adsorptive capacity, and decrease the phosphorus concentration by adsorption. So, the main mechanism of phosphorus removal is coordination settlement and floc adsorption. In addition, it still includes the net capturing and enmeshment function.

In addition, the coagulation function of PAC is related to the basicity [12], for the $\mathrm{pH}$ at range of $5.6-7.2$, the larger the basicity, the effect of purification is better. But for the $\mathrm{pH}$ large than 7.5, the purification effect is not related to the basicity. For some kind of raw water, there is a best value of basicity for its coagulation effect. It has demonstrated [11] that the best $\mathrm{pH}$ is in the range from 5.0 to 8.2 when the PAC is used to remove the SRP. A research [13] has found that the best $\mathrm{pH}$ is 6.5 for removing phosphorus by PAC. The result showed that the best $\mathrm{pH}$ is 7 - 9 in the experiment, so the best $\mathrm{pH}$ should be 6 - 8 when using PAC to remove phosphorus.

As to the aluminum concentration of effluent water, the aluminum concentration of influent water is 0.033 $\mathrm{mg} / \mathrm{L}$, the aluminum concentration of supernatant in sedimentation tank was test at $0.66 \mathrm{mg} / \mathrm{L}$. It present that the aluminum concentration would rise when using poly aluminum chloride as coagulant.

\section{Comparison of Effect of Three Coagulants}

The effects of three coagulants are presented in Table 1. As can be seen from the table, all of three coagulants could remove phosphorus and reach the best effect in solution of moderate $\mathrm{pH}$ value. It has found [14] that if it want to obtain the same removal effect, the PAC would be economic than aluminum sulfate. The aluminum is a kind of low toxic matter, if it enter the body of human, it would accumulate and cause biological and chemical reaction, the nutrients and trace element would lose or precipitate, consequently the physiological function of some organs would be damaged. The effect of PAC is better than the alums, since the important advantage is that the dosage is less, the growing speed is fast and the particulate is large, and it is intend to settle. The reactive time is short, the applicable water temperature and $\mathrm{pH}$ value is in wide range (5 - 9), but the dosage is not overdue, or else it would cause the muddy [15].

Qiuyang Wang has researched [7] that the effective of aluminum chloride is better than poly aluminum chloride when to remove the phosphorus in waste water. But the water sample is manmade in which the phosphorus is SRP only.

\section{Conclusion}

From the discussion, one may conclude that phosphorus removal by three coagulants has shown that the $\mathrm{pH}$, best dosage are different for three coagulants when to remove low concentration phosphorus in the water plant. The efficiency of poly aluminum chloride is the largest, up to $80 \%$, followed by the aluminum chloride and the aluminum sulfate. Three coagulants could remove both PP and SP. The lowest proportion of aluminum to phosphorus of poly aluminum chloride is 63 , followed by the aluminum chloride and the aluminum sulfate. From the comparison, the PAC should be a priority to be as the coagulant to remove low concentration phosphorus. Our results lack the research on the other metal salts, therefore, further studies are still necessary for other coagulants.

Table 1. Comparison of phosphorus removal efficiency of aluminum salts.

\begin{tabular}{|c|c|c|c|c|}
\hline Coagulant & $\begin{array}{c}\text { The largest removal rate } \\
\text { (\%) }\end{array}$ & $\begin{array}{l}\text { The best dosage } \\
\text { (mg/L) }\end{array}$ & The best $\mathrm{pH}$ & $\begin{array}{l}\text { The proportion of aluminum to } \\
\text { phosphorus }\end{array}$ \\
\hline Aluminum chloride & 74.9 & 50 & $6.5-8.5$ & 84 \\
\hline Aluminum sulfate & 62 & 40 & $5-9$ & 223 \\
\hline Poly aluminum chloride & 80 & $30-50$ & $6-8$ & 63 \\
\hline
\end{tabular}




\section{Acknowledgements}

This work was financed by Key Science and Technology Financing Projects of Ministry of Education (211002), General Program of Science and Technology Development Project of Beijing Municipal Education Commission (KM201110016009) and Major Science and Technology Program for Water Pollution Control and Treatment (2010ZX07320-002).

\section{References}

[1] Miettinen, I.T., Vartiainen, T. and Martikainen, P.J. (1997) Phosphorus and Bacterial Growth in Drinking Water. Applied and Environmental Microbiology, 63, 3242-3245.

[2] Yu, X., Zhang, X. and Wang, Z. (2003) Phosphorus as A Limiting Nutrient in Drinking Water Biological Treatment. Environmental Science, 24, 57-62.

[3] Sang, J., Yu, G., Zhang, X. and Wang Z. (2003) Relation between Phosphorus and Bacterial Regrowth in Drinking Water. Environmental Science, 24, 81-84.

[4] Sang, J., Zhang, X., Zhou, H. and Wang, Z. (2003) Study on Total Phosphorus as Controlling Parameter of Drinking Water Biological Stability. Advances in Water Science, 14, 720-724.

[5] Sathasivan, A., Ohgaki, S., Yamamoto K. and Kamiko, N. (1997) Role of Inorganic Phosphorus in Controlling Regrowth in Water Distribution System. Water Science Technology, 35, 37-44. http://dx.doi.org/10.1016/S0273-1223(97)00149-2

[6] Auvray, F., Hullebusch, E.D., Deluchata, V. and Baudu, M. (2006) Laboratory Investigation of the Phosphorus Removal (SRP and TP) from Eutrophic Lake Water Treated with Aluminum. Water Research, 40, 2713-2719. http://dx.doi.org/10.1016/j.watres.2006.04.042

[7] Wang, Q., Li, T., Wang, D. Chen, H., Chen, Y. and Zhang, S. (2008) Comparison of Phosphorus Removal by Various Coagulants. Water Technology, 2, 33-36.

[8] Liang, C., Deng, H., Su, Y. and Li, H. (2006) Study on the Enhanced Coagulation Effect of Polyferric Sulfate and Aluminum Sulfate for Removal of Humic Acid. Water Purification Technology, 25, 27-30.

[9] Hua, D. (2004) A Comparison Investigation of the Dye Decolorization by the Chitosan, Aluminum Sulphate or Polyaluminum Chloride in Waste Water, Journal of Qingdao University, 19, 65-68.

[10] Xie, W., Wang, Q., Ma, H., Ohsumi, Y. and Ogawa, H.I. (2005) Study on Phosphorus Removal Using a Coagulation System. Process Biochemistry, 40, 2623-2627. http://dx.doi.org/10.1016/j.procbio.2004.06.056

[11] Wang, H., Yang, M., Tang, G. and Zhao, J. (2004) Study on Phosphorus Removal by Polyaluminum Chloride. World of Chemical, 45, 7-10.

[12] Huang, D. and Liao, S. (2004) Analysis and Discussion of the Basicity of Polyaluminum Chloride. Industrial Water Treatment, 24, 52-54.

[13] Feng, Q. (2007) Study on Advanced Treatment Technique of Phosphorus Removal in Drinking Water. Master Thesis, Beijing University of Technology, Beijing.

[14] Pan, Y. and Chen, R. (2006) Comparison of Coagulation Effect on Water Treatment by Polyaluminum Chloride and Aluminum Sulfate. Chemical Production and Technology, 13, 60-62.

[15] Chu, J. (2000) Development of Research on Coagulants in Water Treatment. Journal of Taian Teachers College, 22, 40-42. 
Scientific Research Publishing (SCIRP) is one of the largest Open Access journal publishers. It is currently publishing more than 200 open access, online, peer-reviewed journals covering a wide range of academic disciplines. SCIRP serves the worldwide academic communities and contributes to the progress and application of science with its publication.

Other selected journals from SCIRP are listed as below. Submit your manuscript to us via either submit@scirp.org or Online Submission Portal.
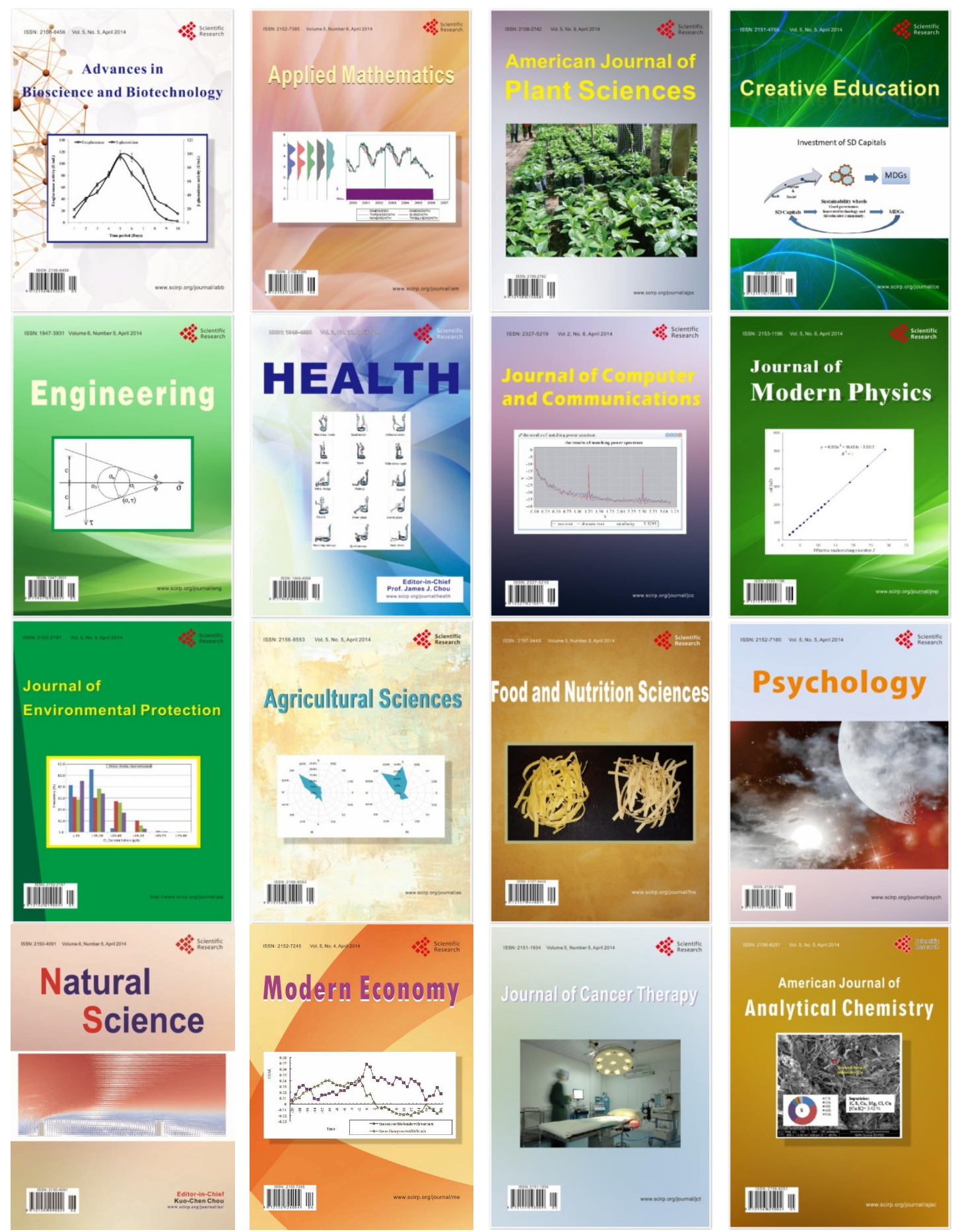